\title{
SASKATCHEWAN TURKEY VULTURE NESTS, 1896-2002
}

C. STUART HOUSTON, 863 University Drive, Saskatoon SK S7N 0J8

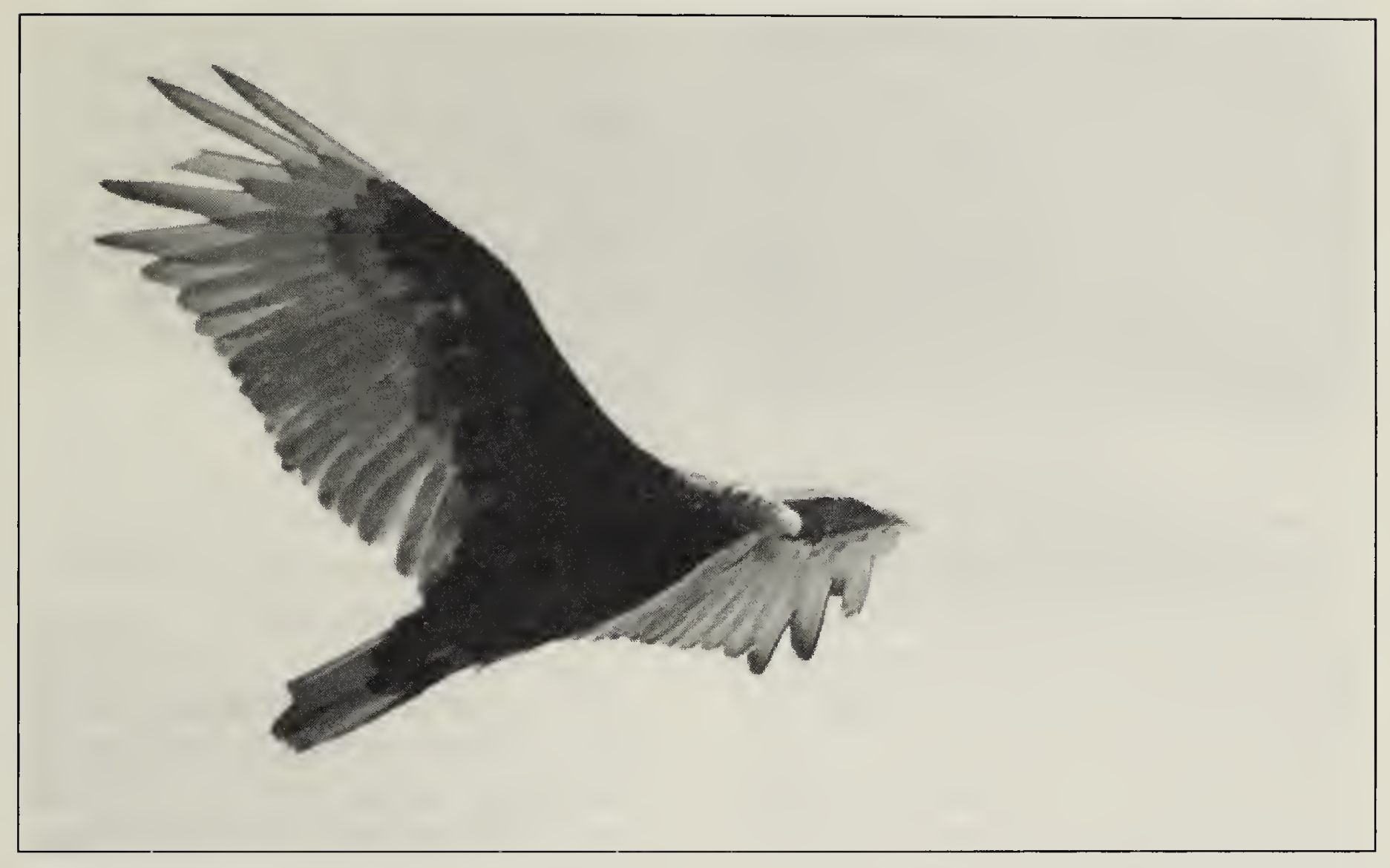

Mossman reviewed the breeding records available for the midwestern and Great Plains states, and classed Turkey Vultures as "local and uncommon breeders in the Dakotas." As of 1991, there were six breeding records for North Dakota and two for South Dakota, one of which was a pair nesting in a deserted house.

By 1969, 13 Turkey Vulture nests had been reported for Saskatchewan, which is at the northern edge of the species' range. ${ }^{4}$ The nine that were specifically described were on the ground: four in caves, four in or under large logs, and one beneath a large rock.

This article presents information on 30 additional Turkey Vulture nests in Saskatchewan. Three of these are based on 1890s museum egg records not previously analyzed. An open-sided nest found on the ground in 1959 and not reported earlier, is also included. The others are nests found after the 1969 report and up until 2002, the first year that Turkey Vulture nests were found in the Saskatoon Bird Area. ${ }^{5}$ They are grouped below according to nest location: 11 nests in caves; 4 nests in brush-piles and thick tangles of dense vegetation; 11 nests in deserted farm buildings.

\section{Egg sets in museums:}

1896, June 8. Pasqua Lake, under fallen tree on side of hill at west end of Pasqua Lake. Two fresh eggs, now in Western Foundation of Vertebrate Zoology, Camarillo, CA, collected by Edward Arnold.

1898, May 17. Ten $\mathrm{km}$ south of Moose Jaw. Egg, now in National Museum of Canada, Ottawa, collected by H. Roy Ivor. 
1898, May 22. Moose Jaw, under bushes on side of hill. Two fresh eggs, now in Western Foundation of Vertebrate Zoology, Camarillo, CA, collected by Edward Arnold.

\section{Nest on ground, open on one side:}

1959, June 10 and 12, Jabe Lake, Moose Mountain Provincial Park, nest with one egg on ground, completely open on one side but dense cover made nest and egg invisible from above. On island that also contained cormorant nests in trees, found by R.W. Fyfe (R.W. Fyfe, pers. comm.) and Fred Lahrman. $^{7}$

\section{Caves:}

1970. Chitek Lake, cave occupied by vultures on sandy south shore of island, found by Frank Martens and Les Arndt (Riome footnote to Schmidt ${ }^{8}$ ).

1972, June 18. Southwest of Eston, two tiny young in cave in river bank. They were banded on July $16 .^{8}$

1974, July 14. Northwest of Ravenscrag, cave in conglomerate cliff on Saville ranch, two young banded by the author.

1978, May 6. Canopus, pair present at cave used by vultures in previous years, found by Tom Sadler (pers. comm.).

1980, July 11. Canopus, one young in cave in sandstone outcrop. On August 7 , the young was found dead $20 \mathrm{~m}$ down the hill below the cave by George F. Ledingham and Gary G. Anweiler (pers. comm.).

1980, August 13. Adams Lake, Cypress Hills, two young in cave in conglomerate cliff, 8 feet below top of cliff, photographed by Lloyd Thiele. Both young flew out of the nest when it was approached on 16 August by G.F.
Ledingham (pers. comm.).

1984, August 12. Ministikwan Lake, two young in wave-excavated cave under roots of large dead tree on shore, found by Frank Scott and Brad Tokaruk. ${ }^{9}$

1989, July 11. Roan Mare Coulee, Big Muddy, two young in small cave, one of them photographed by Tom Lichter. ${ }^{2}$

1989, August 25. Big Beaver, two young perched above presumed cave that eluded detection earlier near Marshall Cemetery. ${ }^{2}$

1992, July 5. Ravenscrag, two young in cave on Saville ranch, sighted by Jim Saville (same cave as in the 1974 record above (pers. comm.)

1996. Mankota Community Pasture, south of Mankota, young last seen in nest cave about 1996 by Dwight Gavelin, pasture manager (pers. comm.).

\section{Brush-piles:}

1976. West of Edam, nest with one young in large brush-pile, photographed by Ken A. Smith. ${ }^{10}$

1976, August 10. Two miles east of Mervin, one large young in bulldozed brushpile, section 26-50-22 w3, found by Keith Roney (pers. comm.).

1978. Moose Mountain Provincial Park. "An active nest was located in 1978." "11 Stelfox (pers. comm.) suspects this record was obtained by Terra Environmental Consultants Ltd., when in 1978 they made a 120-page wildlife inventory report preparatory to the 1980 provincial park master plan study.

1980. Greenwater Lake Provincial Park, two nests under brush-piles, both found by Odd Steiestol. ${ }^{3}$ 


\section{Deserted buidings:}

1982, July. Outside north edge of Moose Mountain Provincial Park, section 3 , township 11, range $2 \mathrm{w} 2$, three miles east of Highway 9, on land of Claire Rogers, accountant at Kenosee Lake Provincial Park. Two young in empty granary, when visited by conservation officer Fred Baran (pers. comm.). Previously unreported, this record now rates as the first vulture nest in a building in Saskatchewan.

1983, July $7.35 \mathrm{~km}$ northeast of Biggar, two nestlings in upstairs of deserted house, found in late June by Jack de Bussac and Norman Smith. ${ }^{12}$

1984, June 15. North of Preeceville and west of Lady Lake, two eggs in upstairs room of deserted house on wildlife lands. Only one nestling was present on 17 July. ${ }^{1,3}$

1984, July 24. Boggy Creek valley near Runnymede, two young in manger of old barn, found by Bernard de Vries (pers. comm.).

1987, August. Southwest of Swan Plain post office, two young in attic of deserted house, found by Barry and Karen Griffith. ${ }^{3}$

1990, mid-June. Southwest of Porcupine Plain, nest with two eggs in deserted house, found by Ken Wallin. ${ }^{3}$

1990 (or possibly 1989). Preeceville, two young in deserted log building 3 $\mathrm{km}$ north and $1 \mathrm{~km}$ mile east of Preeceville, found by Leona Pollock (pers. comm.).

1999. Eight km south of Grayson, single young in deserted building. Apparently deserted by its parents, it was fed by Pat Taillon until it flew in October (pers. comm.).
2000 and 2002. Loch Lomond near Preeceville, two young raised each year in deserted house found by Dave Weiman (pers. comm.).

2000, July. Sixteen $\mathrm{km}$ north of Lilac siding, Turkey Vulture pair regularly flying in and out of deserted one-story house, observed by Walter Jess (pers. comm.).

\section{Acknowledgments}

I thank the many observers who have contributed to these records over many years.

1. BEAULIEU, R. 1985. Abandoned house nest site for Turkey Vulture. Blue Jay 43:46-48.

2. BJORKLUND, C.F. 1990. Turkey Vultures in the Big Muddy. Blue Jay 48:103.

3. HOOPER, D.F. 1992. Birds of East-central Saskatchewan, Kelvington to Kelsey Trail. Special Publication \#18, Saskatchewan Natural History Society.

4. HOUSTON, C.S. 1969. Turkey Vulture breeding records in Saskatchewan. Blue Jay 27:37-39.

5. HOUSTON, C.S., M.J. Stoffel, and A.R. Smith. 2002. Three Turkey Vulture pairs nest in Saskatoon bird area. Blue Jay 60:206-209.

6. MOSSMAN, M.J. 1991. Black and Turkey Vultures, pp. 3-22 in: Midwest Raptor Management Symposium and Workshop, National Wildlife Federation Scientific \& Technical Series \#15.

7. NERO, R.W., and M.R. LEIN. 1971. Birds of Moose Mountain, Saskatchewan. Special Publication \#7, Sask. Natural History Society.

8. SCHMIDT, J.W. 1973. Cave-nesting Turkey Vultures of the south Saskatchewan. Blue Jay 31:58.

9. SCOTT, F. 1985. Northern Turkey Vulture nest. Blue Jay 43:48.

10. SMITH, K.A. 1977. Vulture sighting. Fish and Game Sportsman 9(3):12.

11. STELFOX, H.A. 1980. Wildlife changes in southeastern Saskatchewan. Blue Jay 38:69-79.

12. WAPPLE, G. 1985. Nesting Turkey Vulture near Biggar, Saskatchewan. Blue Jay 43:44-46. 